\title{
Organization and distribution of glomeruli in the bowhead whale olfactory bulb.
}

\section{$\operatorname{AUTHOR}(S)$ :}

Kishida, Takushi; Thewissen, JGM; Usip, Sharon; Suydam, Robert S.; George, John C.

\section{CITATION:}

Kishida, Takushi ...[et al]. Organization and distribution of glomeruli in the bowhead whale olfactory bulb.. PeerJ 2015, 2015(3): e897.

\section{ISSUE DATE:}

2015-04-28

URL:

http://hdl.handle.net/2433/218222

RIGHT:

(C) 2015 Kishida et al. Distributed under Creative Commons CC-BY 4.0 


\title{
PeerJ
}

\section{Organization and distribution of glomeruli in the bowhead whale olfactory bulb}

\author{
Takushi Kishida $^{1}$, JGM Thewissen ${ }^{2}$, Sharon Usip ${ }^{2}$, Robert S. Suydam ${ }^{3}$ \\ and John C. George ${ }^{3}$ \\ ${ }^{1}$ Wildlife Research Center, Kyoto University, Kyoto, Japan \\ ${ }^{2}$ Department of Anatomy and Neurobiology, Northeast Ohio Medical University, Rootstown, \\ $\mathrm{OH}, \mathrm{USA}$ \\ ${ }^{3}$ Department of Wildlife Management, North Slope Borough, Barrow, AK, USA
}

\section{ABSTRACT}

Although modern baleen whales (Mysticeti) retain a functional olfactory system that includes olfactory bulbs, cranial nerve I and olfactory receptor genes, their olfactory capabilities have been reduced to a great degree. This reduction likely occurred as a selective response to their fully aquatic lifestyle. The glomeruli that occur in the olfactory bulb can be divided into two non-overlapping domains, a dorsal domain and a ventral domain. Recent molecular studies revealed that all modern whales have lost olfactory receptor genes and marker genes that are specific to the dorsal domain. Here we show that olfactory bulbs of bowhead whales (Balaena mysticetus) lack glomeruli on the dorsal side, consistent with the molecular data. In addition, we estimate that there are more than 4,000 glomeruli elsewhere in the bowhead whale olfactory bulb, which is surprising given that bowhead whales possess only 80 intact olfactory receptor genes. Olfactory sensory neurons that express the same olfactory receptors in rodents generally project to two specific glomeruli in an olfactory bulb, implying an approximate 1:2 ratio of the number of olfactory receptors to the number of glomeruli. Here we show that this ratio does not apply to bowhead whales, reiterating the conceptual limits of using rodents as model organisms for

Submitted 19 December 2014 Accepted 28 March 2015 Published 28 April 2015

Corresponding author Takushi Kishida, taku.kishida@gmail.com

Academic editor

Nicholas Pyenson

Additional Information and Declarations can be found on page 6

DOI 10.7717/peerj.897

Copyright

2015 Kishida et al.

Distributed under

Creative Commons CC-BY 4.0

\section{OPEN ACCESS} understanding the initial coding of odor information among mammals.

Subjects Evolutionary Studies, Neuroscience, Zoology, Anatomy and Physiology, Histology Keywords Brain, Baleen whale, Cetacea, Olfactory marker protein, Mysticeti, Olfactory receptor

\section{INTRODUCTION}

Terrestrial mammals generally have a well-developed sense of smell that can discriminate millions of odors using hundreds or thousands of olfactory receptors (ORs) (Nei, Niimura \& Nozawa, 2008). Odorants are detected by ORs expressed in the cell membrance of the olfactory sensory neurons (OSNs), which project to the glomeruli of the olfactory bulbs (OBs). Each OSN expresses only one OR gene (Serizawa, Miyamichi \& Sakano, 2004), and OSNs expressing the same OR converge their axons to a specific set of glomeruli in the olfactory bulb (Mombaerts et al., 1996). Using mice and rats as model organisms, it has been reported that any one OR is typically represented by two glomeruli (Mombaerts et al., 1996; Ressler, Sullivan \& Buck, 1994; Vassar et al., 1994), which indicates that the number of 
glomeruli in the $\mathrm{OB}$ is approximately twice that of the number of $O R$ genes in its genome. However, it is still unclear whether these findings can be extended to other mammals.

The glomerular layer of the $\mathrm{OB}$ can be classified into two domains, the dorsal (D) domain and the ventral (V) domain, based on the expression patterns of domain-specific marker genes (Imai \& Sakano, 2007). The D domain is defined by the expression of the OMACS gene (Imai \& Sakano, 2007; Oka et al., 2003), and the V domain is defined by the expression of the OCAM gene (Imai \& Sakano, 2007; Yoshihara et al., 1997). All mammalian $O R$ genes can be classified into two subfamilies, class I and class II, based on sequence similarities (Niimura \& Nei, 2006). The OSNs expressing class I ORs are projected to the D domain of the OB, while OSNs expressing class II ORs are projected to both D and V domains (Imai \& Sakano, 2007; Tsuboi et al., 2006).

Cetaceans are an order of mammals that originated in the early Eocene epoch and they derive from terrestrial artiodactyls (Thewissen et al., 2009). Extant cetaceans are classified into two monophyletic suborders, Odontoceti (toothed whales) and Mysticeti (baleen whales). Modern cetaceans are known to have reduced the olfactory capabilities profoundly during their evolution, and living odontocetes have no nervous system structures that mediate olfaction (Oelschläger, Ridgway \& Knauth, 2010). On the other hand, at least some species of mysticetes have a fully equipped olfactory system and OB (Thewissen et al., 2011), but the number of functional OR genes is remarkably reduced. Terrestrial mammals, including cows, which are terrestrial relatives of whales, possess approximately 1,000 intact OR genes (Niimura, Matsui \& Touhara, in press; Niimura \& Nei, 2007). By contrast, minke and Antarctic minke whales (Balaenoptera acutorostrata and B. bonaerensis) possess only 60 intact OR genes (Kishida et al., 2015; Yim et al., 2014), and 56 of these are included in the class II OR subfamily (Kishida et al., 2015). In addition, genomic analyses have revealed that all modern mysticetes lack functional OMACS genes (Kishida et al., 2015). Based on these findings, it appears that, although mysticetes have fully equipped olfactory systems, their OB lacks the D domain (Kishida et al., 2015).

These molecular data suggest that mysticetes lack glomeruli on the dorsal side of their $\mathrm{OB}$. In addition, because mysticetes possess a very small number of $O R$ genes, it is expected that the number of glomeruli in their $\mathrm{OB}$ is also very small. However, no detailed study of the distribution and organization of glomeruli in mysticete $\mathrm{OB}$ has been reported to date. In this study, we provide the distribution of glomeruli in bowhead whales (Balaena mysticetus) and present data that test whether the mysticete OR:glomeruli ratio compares with the 1:2 ratio observed in mice and rats.

\section{MATERIALS AND METHODS}

Tissues of bowhead whales, details of which are shown in Table 1, were sampled from subsistence hunts in northern Alaska, USA, under NOAA/NMFS permit 814-1899. Whale OBs were fixed in $10 \%$ buffered formalin and processed using standard histological techniques. Section thickness was $6 \mu \mathrm{m}$. Details regarding laboratory procedures are described by Thewissen et al. (2011). 
Table 1 Specimens studied.

\begin{tabular}{lllllll} 
Specimen no. & Species & Sex & Length $(\mathbf{m})$ & Sampling date & Sectional plane & $\begin{array}{l}\text { No. of stained } \\
\text { sections }\end{array}$ \\
\hline $09 \mathrm{~B} 11$ & Balaena mysticetus & Female & 7.2 & Sep. 11, 2009 & Coronal & 5 \\
$09 \mathrm{~B} 14$ & Balaena mysticetus & Female & 10.2 & Sep. 14, 2009 & Horizontal & 1 \\
\hline
\end{tabular}

Glomeruli are labeled by the expression of olfactory marker protein (OMP) (Danciger et al., 1989; Smith et al., 1991). The ImmunoCruz goat ABC staining system (catalog number sc-2023; Santa Cruz Biotechnology, Inc., Dallas, Texas, USA) and a rabbit polyclonal anti-OMP antibody (catalog number sc-67219; Santa Cruz Biotechnology, Inc., Dallas, Texas, USA) were used for immunohistochemistry, following the standard protocol attached to the $\mathrm{ABC}$ staining system kit. Antibody dilution was 1:150. The DAB-stained sections were counterstained with thionin, and then mounted on permanent slides. The number of glomeruli on each slide was counted manually, as shown in Figs. S1-S5. The numbers of glomeruli between these slides were estimated by the following formula:

$[f(n-m+1)+r m] /(n+1)$

where, $n$ is the number of estimated slides between counted slides (slide A and slide B), $f$ is the number of glomeruli in slide $\mathrm{A}, r$ is the number of glomeruli in slide $\mathrm{B}$, and the number of glomeruli on the $m$-th slide among $n$ slides is estimated $(m=1,2 \ldots, n)$.

In order to reconstruct a three-dimensional (3D) image of the $\mathrm{OB}$, horizontal sections of the whole $\mathrm{OB}$ of a bowhead whale (specimen number 09B14) were prepared and every 5th slice was stained with thionin, mounted on permanent slides and photographed. Using AMIRA software (FEI Visualization Sciences Group, Burlington, Massachusetts, USA) ver. 5.4.1, these images were aligned with manual adjustments, and 3D reconstructed. A STL-formatted image of the 3D bowhead whale $\mathrm{OB}$ can be obtained under the following link (http://dx.doi.org/10.6084/m9.figshare.1295197).

We downloaded the bowhead whale genome assembly (Keane et al., 2015), and the OR genes were identified using TBLASTN program ver. 2.2.29 (Altschul et al., 1997). For details of $O R$ gene identification and class I/II classification, we followed the methods used for identifying minke whale OR genes by Kishida et al. (2015).

\section{RESULTS AND DISCUSSION}

Figure 1 shows $\mathrm{OB}$ glomeruli distribution patterns of bowhead whales. The shape of cetacean $\mathrm{OB}$ is not similar to that of terrestrial mammals, such as mice, in having a olfactory ventricle that is wide open dorsally, and with few glomeruli on the dorsal side of the OB. This finding is consistent with our genomic data showing that modern mysticetes lack receptors and marker proteins that are specific to the D domain of the OB (Kishida et al., 2015). We conclude that, from both genomic and morphological points of view, mysticete OB lacks the D domain. D domain-ablated mice fail to show innate avoidance 
a

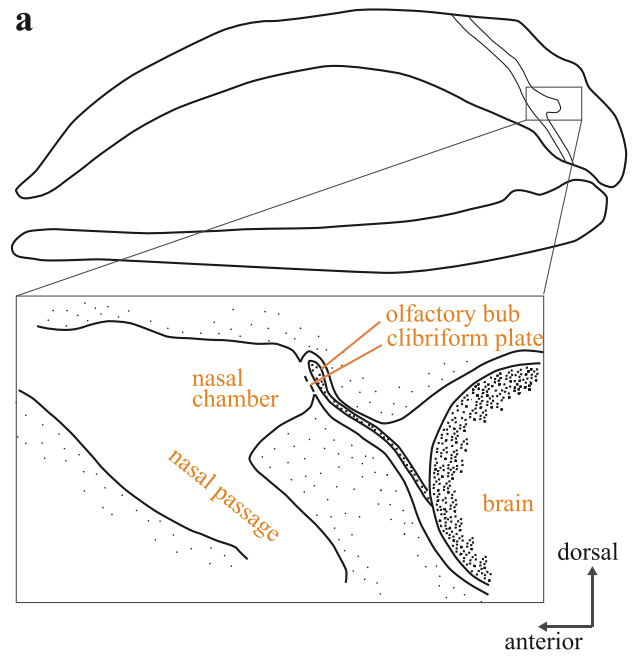

b

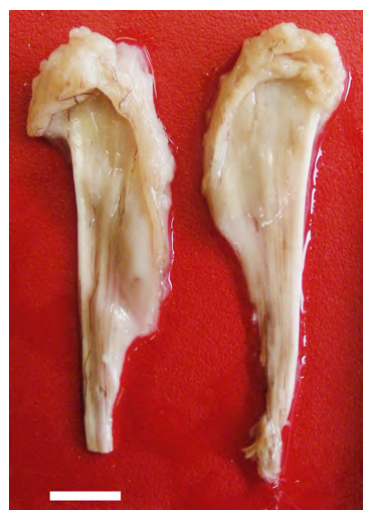

c

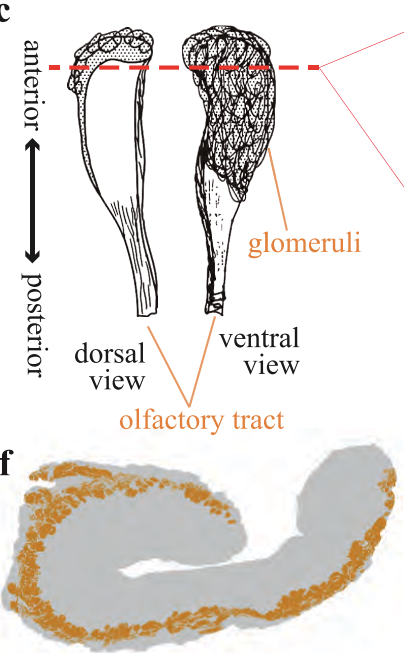

d

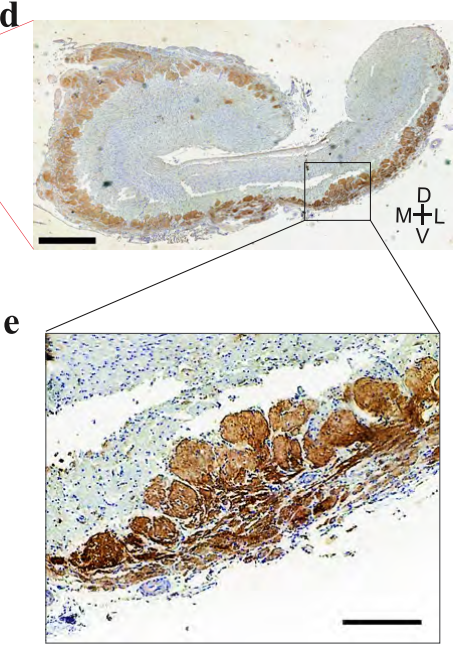

Figure 1 Olfactory bulb of the bowhead whale brain. (A) Diagram of the location of olfactory bulb in a sagittal section through the balaenid skull (modified after Thewissen et al. (2011)) (B) Dorsal view of the left and right OBs of bowhead whale (specimen 09B14). Scale bar, 10 mm. (C) Diagram of the dorsal and ventral view of the bowhead whale right OB. Coronal section (D) was cut at approximately the red dashed line.

(D) Coronal section of the right olfactory bulb of bowhead whale specimen no. 09B11 (section195c). Glomeruli were stained with DAB using anti-OMP antibody, and the whole tissue was counterstained with thionin. D, dorsal; L, lateral; M, medial; V, ventral. Scale bar, 1 mm. (E) Details of glomeruli, enlarged the boxed region in (D). Scale bar, $240 \mu \mathrm{m}$. (F) A schematic view of the distribution of glomeruli of the coronal section of the bowhead whale $\mathrm{OB}$.

behavior against odors of predators and spoiled foods (Kobayakawa et al., 2007), and it is possible that bowhead whales lack olfactory capabilities related to innate avoidance behaviors against such odors.

To test the OR: glomeruli ratio in mysticetes, we counted the number of glomeruli on five coronal sections, as shown in Fig. 2. We observed that the numbers of glomeruli shown in Fig. 2 is likely to be an underestimate of the actual number because some glomeruli cannot be discriminated clearly and were not counted. Generally, four coronal sections were mounted in one slide, and the thickness of each section was $6 \mu \mathrm{m}$. It is estimated that 10 slides, containing 40 sections, correspond to $240 \mu \mathrm{m}$. Because glomeruli are generally less than $240 \mu \mathrm{m}$ in diameter (Fig. 1E, Figs. S1-S5 (coronal sections) and S6 (a horizontal section)), we expected that new glomeruli should appear at most every 10th slide. Therefore, we roughly estimated the number of glomeruli in approximately every 10th slide (Table S1). Surprisingly, this calculation for bowhead whale OB results in approximately 4,000 glomeruli, a number much higher than that of mice $(1,600-1,800)$ (Royet et al., 1988; Taniguchi et al., 2003). We nonetheless consider this value to be an underestimate as explained above, and because the slides posterior of slide 518 were not examined (most of the glomeruli are located anterior of this slide).

Whole genome sequence data are required to obtain the repertoire of $O R$ genes. Recently, a bowhead whale genome assembly was published (Keane et al., 2015) and we identified the $O R$ gene repertoire in this genome assembly. Eighty intact and 11 truncated (i.e., lacking of $3^{\prime}$ and/or $5^{\prime}$ sequence(s) due to the fragmented scaffolds and/or contig gaps) OR gene sequences were identified (Table S2). Among these 91 OR sequences, only 


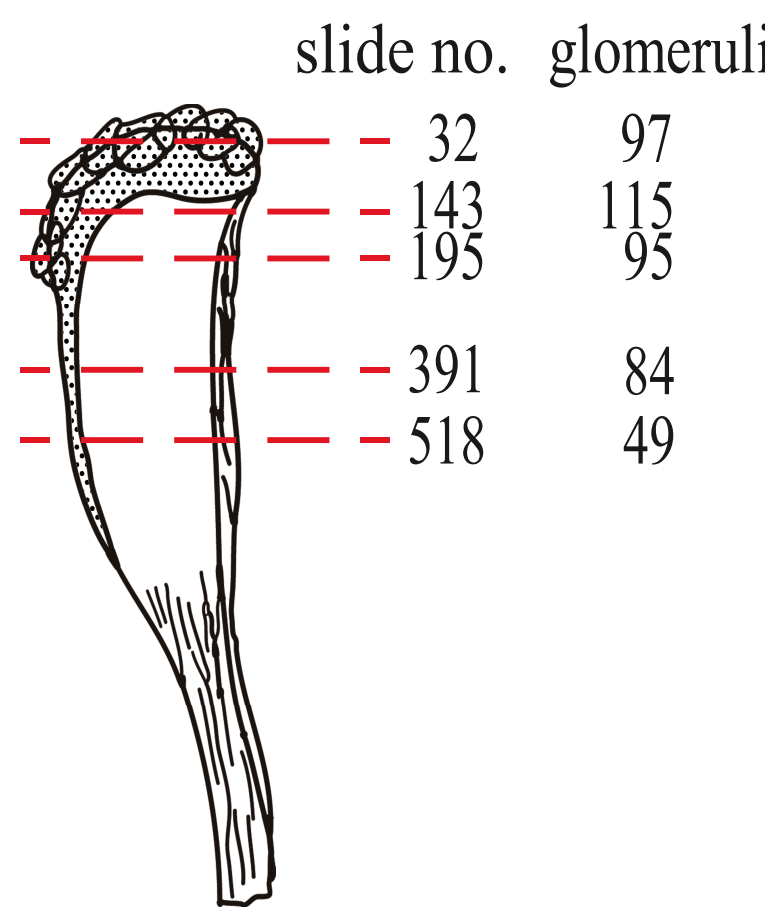

Figure 2 Nos. of glomeruli in five coronal sections investigated in this study. Sections were cut at approximately the red dashed lines. Detail pictures of the sections are available as Figs. S1 (slide no. 32), S2 (slide no. 143), S3 (slide no. 195), S4 (slide no. 391) and S5 (slide no. 518).

four genes were classified into class I (Table S2), including OR51E1 and OR51E2, which are not involved in olfaction (Kishida et al., 2015; Niimura, Matsui \& Touhara, in press; Weng et al., 2006; Xu et al., 2000), supporting our view that bowhead whales OB lack the D domain. The number of $O R$ genes in the bowhead whale genome is much fewer than the number of glomeruli in their OB, and thus we conclude that the OR: glomeruli ratio is not 1:2 in bowhead whales.

Humans are also reported to possess higher numbers of glomeruli $(3,000-9,000)$ than the number of OR genes (350) (Maresh et al., 2008), similar to bowhead whales. Both humans and whales are known to have reduced their OR gene repertoires profoundly in their evolutionary pathways (Kishida et al., 2015; Matsui, Go \& Niimura, 2010). It is possible that, in whales and humans, the evolutionary decline in glomerulus numbers proceeds at a slower rate than the decline of $O R$ genes, which causes the aberrant ratio. Following this explanation, the ancestors of both whales and humans are expected to have a ratio of numbers of $O R$ genes to glomeruli that is greater than 0.5. However, cows, a terrestrial relatives of whales for whom whole genome sequence data are available, possess approximately 1,000 OR genes (Niimura, 2009; Niimura \& Nei, 2007), and other boreoeutherian mammals, including the last common ancestors of all modern boreoeutherians, also possess approximately 1,000 OR genes or less (Niimura, 2009). Therefore, we predict that whale ancestors would be expected to possess at most $\sim 1,000$ OR genes, a much lower number than the number of glomeruli in whale OB. Similarly, the last common ancestors of all modern primates have been estimated to possess 585 
OR genes (Matsui, Go \& Niimura, 2010), a much lower number than the number of glomeruli in human OB. We speculate that the OR:glomeruli ratios are not fixed to 1:2 among mammals.

\section{CONCLUSION}

Our results show that bowhead whale OB lacks glomeruli on the dorsal side, in accordance with molecular data showing that all modern mysticetes lack receptors and marker proteins specific to the $\mathrm{D}$ domain of the $\mathrm{OB}$.

There is a much larger number of glomeruli in the bowhead whale OB than expected from the number of $O R$ genes, indicating that the OR:glomeruli ratios are not always 1:2 among mammals.

\section{ACKNOWLEDGEMENTS}

We are grateful to Yoshihiro Yoshihara (RIKEN), Meghan Moran and Denise McBurney (NEOMED) for helpful comments and technical advice. We wish to thank the Captains of the Barrow Whaling Captains Association and the Alaska Eskimo Whaling Commission for allowing us to examine and collect samples from their whales. We especially thank the hunters that allowed us to do detailed sampling: H Brower, N Olemaun, and G Ahmaogak. This study would not have been possible without their support.

\section{ADDITIONAL INFORMATION AND DECLARATIONS}

\section{Funding}

This study was financially supported by MEXT KAKENHI (grant no. 24770075) to Takushi Kishida. Support for JGM Thewissen was provided by the National Science Foundation (EAR) and the North Slope Borough, Barrow, Alaska. The funders had no role in study design, data collection and analysis, decision to publish, or preparation of the manuscript.

\section{Grant Disclosures}

The following grant information was disclosed by the authors:

MEXT KAKENHI: 24770075.

National Science Foundation.

North Slope Borough.

\section{Competing Interests}

JGM Thewissen is an Academic Editor for PeerJ.

\section{Author Contributions}

- Takushi Kishida conceived and designed the experiments, performed the experiments, analyzed the data, contributed reagents/materials/analysis tools, wrote the paper, prepared figures and/or tables, reviewed drafts of the paper.

- JGM Thewissen performed the experiments, contributed reagents/materials/analysis tools, wrote the paper, reviewed drafts of the paper. 
- Sharon Usip performed the experiments, prepared figures and/or tables, reviewed drafts of the paper.

- Robert S. Suydam and John C. George performed the experiments, contributed reagents/materials/analysis tools, reviewed drafts of the paper.

\section{Animal Ethics}

The following information was supplied relating to ethical approvals (i.e., approving body and any reference numbers):

Tissues of bowhead whales were sampled under NOAA/NMFS permit 814-1899.

\section{Data Deposition}

The following information was supplied regarding the deposition of related data:

Figshare, http://dx.doi.org/10.6084/m9.figshare.1295197

\section{Supplemental Information}

Supplemental information for this article can be found online at http://dx.doi.org/ 10.7717/peerj.897\#supplemental-information.

\section{REFERENCES}

Altschul SF, Madden TL, Schäffer AA, Zhang J, Zhang Z, Miller W, Lipman DJ. 1997. Gapped BLAST and PSI-BLAST: a new generation of protein database search programs. Nucleic Acids Research 25:3389-3402 DOI 10.1093/nar/25.17.3389.

Danciger E, Mettling C, Vidal M, Morris R, Margolis F. 1989. Olfactory marker protein gene: its structure and olfactory neuron-specific expression in transgenic mice. Proceedings of the National Academy of Sciences of the United States of America 86:8565-8569 DOI 10.1073/pnas.86.21.8565.

Imai T, Sakano H. 2007. Roles of odorant receptors in projecting axons in the mouse olfactory system. Current Opinion in Neurobiology 17:507-515 DOI 10.1016/j.conb.2007.08.002.

Keane M, Semeiks J, Webb Andrew E, Li Yang I, Quesada V, Craig T, Madsen Lone B, Van Dam S, Brawand D, Marques Patrícia I, Michalak P, Kang L, Bhak J, Yim H-S, Grishin Nick V, Nielsen Nynne H, Heide-Jørgensen Mads P, Oziolor Elias M, Matson Cole W, Church George M, Stuart Gary W, Patton John C, George JC, Suydam R, Larsen K, López-Otín C, O’Connell Mary J, Bickham John W, Thomsen B, de Magalhães João P. 2015. Insights into the evolution of longevity from the bowhead whale genome. Cell Reports 10:112-122 DOI 10.1016/j.celrep.2014.12.008.

Kishida T, Thewissen JGM, Hayakawa T, Imai H, Agata K. 2015. Aquatic adaptation and the evolution of smell and taste in whales. Zoological Letters 1:Article 9 DOI 10.1186/s40851-014-0002-z.

Kobayakawa K, Kobayakawa R, Matsumoto H, Oka Y, Imai T, Ikawa M, Okabe M, Ikeda T, Itohara S, Kikusui T, Mori K, Sakano H. 2007. Innate versus learned odour processing in the mouse olfactory bulb. Nature 450:503-508 DOI 10.1038/nature06281.

Maresh A, Rodriguez Gil D, Whitman MC, Greer CA. 2008. Principles of glomerular organization in the human olfactory bulb-implications for odor processing. PLoS ONE 3:e2640 DOI 10.1371/journal.pone.0002640. 
Matsui A, Go Y, Niimura Y. 2010. Degeneration of olfactory receptor gene repertories in primates: no direct link to full trichromatic vision. Molecular Biology and Evolution 27:1192-1200 DOI 10.1093/molbev/msq003.

Mombaerts P, Wang F, Dulac C, Chao SK, Nemes A, Mendelsohn M, Edmondson J, Axel R. 1996. Visualizing an olfactory sensory map. Cell 87:675-686

DOI 10.1016/S0092-8674(00)81387-2.

Nei M, Niimura Y, Nozawa M. 2008. The evolution of animal chemosensory receptor gene repertoires: roles of chance and necessity. Nature Reviews Genetics 9:951-963 DOI 10.1038/nrg2480.

Niimura Y. 2009. Evolutionary dynamics of olfactory receptor genes in chordates: interaction between environments and genomic contents. Human Genomics 4:107-118

DOI 10.1186/1479-7364-4-2-107.

Niimura Y, Matsui A, Touhara K. Extreme expansion of the olfactory receptor gene repertoire in African elephants and evolutionary dynamics of orthologous gene groups in 13 placental mammals. Genome Research In Press.

Niimura Y, Nei M. 2006. Evolutionary dynamics of olfactory and other chemosensory receptor genes in vertebrates. Journal of Human Genetics 51:505-517 DOI 10.1007/s10038-006-0391-8.

Niimura Y, Nei M. 2007. Extensive gains and losses of olfactory receptor genes in Mammalian evolution. PLoS ONE 2:e708 DOI 10.1371/journal.pone.0000708.

Oelschläger HHA, Ridgway SH, Knauth M. 2010. Cetacean brain evolution: dwarf sperm whale (Kogia sima) and common dolphin (Delphinus delphis) — an investigation with high-resolution 3D MRI. Brain, Behavior and Evolution 75:33-62 DOI 10.1159/000293601.

Oka Y, Kobayakawa K, Nishizumi H, Miyamichi K, Hirose S, Tsuboi A, Sakano H. 2003. O-MACS, a novel member of the medium-chain acyl-CoA synthetase family, specifically expressed in the olfactory epithelium in a zone-specific manner. European Journal of Biochemistry 270:1995-2004 DOI 10.1046/j.1432-1033.2003.03571.x.

Ressler KJ, Sullivan SL, Buck LB. 1994. Information coding in the olfactory system: evidence for a stereotyped and highly organized epitope map in the olfactory bulb. Cell 79:1245-1255 DOI 10.1016/0092-8674(94)90015-9.

Royet JP, Souchier C, Jourdan F, Ploye H. 1988. Morphometric study of the glomerular population in the mouse olfactory bulb: numerical density and size distribution along the rostrocaudal axis. The Journal of Comparative Neurology 270:559-568

DOI 10.1002/cne.902700409.

Serizawa S, Miyamichi K, Sakano H. 2004. One neuron-one receptor rule in the mouse olfactory system. Trends in Genetics 20:648-653 DOI 10.1016/j.tig.2004.09.006.

Smith RL, Baker H, Kolstad K, Spencer DD, Geer CA. 1991. Localization of tyrosine hydroxylase and olfactory marker protein immunoreactivities in the human and macaque olfactory bulb. Brain Research 548:140-148 DOI 10.1016/0006-8993(91)91115-H.

Taniguchi M, Nagao H, Takahashi YK, Yamaguchi M, Mitsui S, Yagi T, Mori K, Shimizu T. 2003. Distorted odor maps in the olfactory bulb of semaphorin 3A-deficient mice. The Journal of Neuroscience 23:1390-1397.

Thewissen JGM, Cooper LN, George JC, Bajpai S. 2009. From land to water: the origin of whales, dolphins, and porpoises. Evolution: Education and Outreach 2:272-288.

Thewissen JGM, George J, Rosa C, Kishida T. 2011. Olfaction and brain size in the bowhead whale (Balaena mysticetus). Marine Mammal Science 27:282-294

DOI 10.1007/s12052-009-0135-2. 
Tsuboi A, Miyazaki T, Imai T, Sakano H. 2006. Olfactory sensory neurons expressing class I odorant receptors converge their axons on an antero-dorsal domain of the olfactory bulb in the mouse. European Journal of Neuroscience 23:1436-1444 DOI 10.1111/j.1460-9568.2006.04675.x.

Vassar R, Chao SK, Sitcheran R, Nuñez JM, Vosshall LB, Axel R. 1994. Topographic organization of sensory projections to the olfactory bulb. Cell 79:981-991

DOI 10.1016/0092-8674(94)90029-9.

Weng J, Wang J, Hu X, Wang F, Ittmann M, Liu M. 2006. PSGR2, a novel G-protein coupled receptor, is overexpressed in human prostate cancer. International Journal of Cancer 118:1471-1480 DOI 10.1002/ijc.21527.

Xu LL, Stackhouse BG, Florence K, Zhang W, Shanmugam N, Sesterhenn IA, Zou Z, Srikantan V, Augustus M, Roschke V. 2000. PSGR, a novel prostate-specific gene with homology to a $\mathrm{G}$ protein-coupled receptor, is overexpressed in prostate cancer. Cancer Research 60:6568-6572.

Yim H-S, Cho YS, Guang X, Kang SG, Jeong J-Y, Cha S-S, Oh H-M, Lee J-H, Yang EC, Kwon KK, Kim YJ, Kim TW, Kim W, Jeon JH, Kim S-J, Choi DH, Jho S, Kim H-M, Ko J, Kim H, Shin Y-A, Jung H-J, Zheng Y, Wang Z, Chen Y, Chen M, Jiang A, Li E, Zhang S, Hou H, Kim TH, Yu L, Liu S, Ahn K, Cooper J, Park S-G, Hong CP, Jin W, Kim H-S, Park C, Lee K, Chun S, Morin PA, O'Brien SJ, Lee H, Kimura J, Moon DY, Manica A, Edwards J, Kim BC, Kim S, Wang J, Bhak J, Lee HS, Lee J-H. 2014. Minke whale genome and aquatic adaptation in cetaceans. Nature Genetics 46:88-92 DOI 10.1038/ng.2835.

Yoshihara Y, Kawasaki M, Tamada A, Fujita H, Hayashi H, Kagamiyama H, Mori K. 1997. OCAM: a new member of the neural cell adhesion molecule family related to zone-to-zone projection of olfactory and vomeronasal axons. The Journal of Neuroscience 17:5830-5842. 